\title{
Are Breast Masses in Teenagers Always Benign? Undifferentiated Mesenchymal Sarcoma in a 14-Year-Old Girl
}

\author{
Guven Tekbas $^{\mathrm{a}}$ Tülay Ince ${ }^{\mathrm{b}}$ Murat Kapan ${ }^{\mathrm{c}}$ Faysal Ekici $^{\mathrm{a}}$ \\ Akın Önder $^{c}$ Mehmet Kucukonen $^{d}$ Aslan Bilici $^{\mathrm{a}}$ Hatice Gumus ${ }^{\mathrm{a}}$ \\ aDepartment of Radiology, Dicle University School of Medicine, Diyarbakir, \\ bepartment of Pathology, Goztepe Training and Research Hospital, Istanbul, \\ 'Department of General Surgery, ${ }^{\mathrm{d}}$ Department of Medical Oncology, Dicle University School of Medicine, Diyarbakir, Turkey
}

\section{Keywords}

Breast lump - Sarcoma, undifferentiated .

MRI - Adolescent breast cancer

\section{Summary}

Background: This article is concerned with the evaluation of an adolescent breast mass using imaging methods. Case Report: A 14-year-old girl presented with progressive asymmetric enlargement of the left breast. She had felt a breast lump about 4 months earlier, and over the last 2 months it had been growing progressively. Tumor markers, including AFP, CEA, CA15-3, and CA125, were all normal. Ultrasonography showed a hypoechoichyperechoic, solid mass. Magnetic resonance imaging of the breast revealed a well marginated mass with hypointensity on T1-weighted images and mild hyperintensity on T2-weighted images, which showed mild contrast uptake. Biopsy revealed an undifferentiated malignant mesenchymal sarcoma. The patient underwent mastectomy with axillary lymph node sampling. After the operation, she received 3 cycles of chemotherapy and radiotherapy. Conclusion: Due to the rarity of breast sarcoma and inadequate imaging methods to establish an exact diagnosis, radiologists and clinicians may misdiagnose and merely follow these tumors. As in our case, the histology of the patient may be the leading factor in the management of these tumors. Even in very young patients, progressively growing breast masses should alert the clinician to check for malignancy verified by biopsy.

\section{Schlüsselwörter}

Knoten in der Brust . Sarkom, undifferenziertes .

MRT · Mammakarzinome bei Jugendlichen

\section{Zusammenfassung}

Hintergrund: Dieser Artikel befasst sich mit der Untersuchung einer im Jugendalter aufgetretenen Umfangsvermehrung der Brust mittels bildgebender Verfahren. Fallbericht: Ein 14-jähriges Mädchen wurde mit einer progressiven, asymmetrischen Umfangsvermehrung in der linken Brust vorstellig. Die Patientin hatte 4 Monate zuvor einen Knoten in der Brust bemerkt, der in den letzten 2 Monaten progressiv an Größe zugenommen hatte. Tumormarker - inklusive AFP, CEA, CA15-3 und CA125 waren alle im Normalbereich. Die Ultraschalluntersuchung zeigte einen hypoechoischen/hyperechoischen, festen Knoten. Die magnetresonanztomographische Untersuchung der Brust ergab einen gut abgegrenzten Tumor mit Hypointensität in T1-gewichteten Aufnahmen und milder Hyperintensität in T2-gewichteten Aufnahmen sowie mildem Kontrast-Uptake. Die Biopsie ergab ein undifferenziertes, bösartiges, mesenchymales Sarkom. Es wurde eine Mastektomie mit axillärem LymphknotenSampling durchgeführt. Nach der Operation erhielt die Patientin 3 Zyklen einer Chemo- und Radiotherapie. Schlussfolgerung: Auf Grund der Seltenheit von Mammasarkomen und inadäquaten bildgebenden Methoden zur exakten Diagnosestellung ist es möglich, dass Radiologen und Kliniker eine falsche Diagnose stellen und diese Tumoren lediglich beobachten. So wie in unserem Fall kann die histologische Untersuchung der entscheidende Faktor für das Tumormanagement sein. Selbst bei sehr jungen Patientinnen sollten progressiv wachsende Knoten in der Brust Anlass zur Untersuchung auf Bösartigkeit mit Befundbestätigung mittels Biopsie geben.

\section{KARGER}

Fax +497614520714

Information@Karger.de

www.karger.com (c) 2012 S. Karger GmbH, Freibur

Accessible online at:

www.karger.com/brc
21280 Diyarbakir, Turkey

Tel. +90 5054001263

guvenmakale@gmail.com 


\section{Introduction}

Breast masses or breast enlargements in children and adolescents are generally of a benign nature. The most common mass is fibroadenoma which is constituted $30-50 \%$ of breast masses in a medical series [1, 2]. Malignant cancers are extremely rare in this age group, with phylloides tumor being the most common. Sarcoma of the breast was first described by Chelius in 1821, and this rare entity constitutes $1 \%$ of all breast malignancies [3]. Here, we report an undifferentiated mesenchymal breast sarcoma in a 14-year-old female patient.

\section{Case Report}

A 14-year-old girl presented with progressive asymmetric enlargement of the left breast. She had felt a breast lump about 4 months earlier, which had been growing progressively for the last 2 months. On inspection, the tumor filled the medial quadrants of the breast. The patient had no family history or any risk factors. On physical examination, there was a hard, mobile, and painless palpable mass in the medial quadrant of the left breast. There was no discharge from the left nipple and no palpable axillary lymphadenopathy. All vital signs and the chest X-ray were normal. Hemogram and biochemical analysis were normal. Tumor markers, including AFP, CEA, CA15-3, and CA125, were all normal. Ultrasonography showed a hypoechoic/hyperechoic, solid mass, $120 \times 80 \mathrm{~mm}$ in diameter (fig. 1). On Doppler sonography, the mass had a mild vascularity and smooth borders. There was no evidence of invasion. No pathologic lymph nodes were seen in both axillary regions. Based on the sonography results, a preliminary diagnosis of giant fibroadenoma or phylloides tumor was made. A magnetic resonance imaging (MRI) scan of the breast was performed (figs. 2-3) which revealed a well marginated mass with hypointensity on T1-weighted images and mild hyperintensity on T2weighted images. The mass showed mild contrast uptake, and a type 2 curve was revealed. At the inner-upper quadrant of the left breast, the subcutaneous fat tissue between the mass and the skin was poorly depicted, which raised the suspicion of invasion. Due to the MRI and sonography results, a sonographically guided breast trucut biopsy was performed which revealed an undifferentiated malignant mesenchymal sarcoma. Based on clinical, radiological, and biopsy findings, the lesion was evaluated as locally advanced breast cancer, and a mastectomy with axillary lymph node sampling was performed. Surgical margins were shown to be clear by intraoperative frozen examination. The histopathologic examination demonstrated an undifferentiated sarcoma and negative surgical margins. The tumor had a mesenchymal component which was however not consistent with cystosarcoma phylloides, no epithelial component, and a high mitotic index. On the 6th postoperative day, the patient was discharged from the hospital. She received 3 cycles of chemotherapy (vincristine $0.4 \mathrm{mg} /$ day and adriamycin $10 \mathrm{mg} / \mathrm{m}^{2} /$ day continuous intravenous (IV) infusion days $1-4$, cyclophosphamide $600 \mathrm{mg} / \mathrm{m}^{2}$ IV day 1 , dexamethasone $40 \mathrm{mg}$ orally days $1-4$ ) and radiotherapy (50 Gy) as an adjuvant therapy. Unfortunately, the patient died in the 10th month of follow-up due to recurrent disease and systemic dissemination.

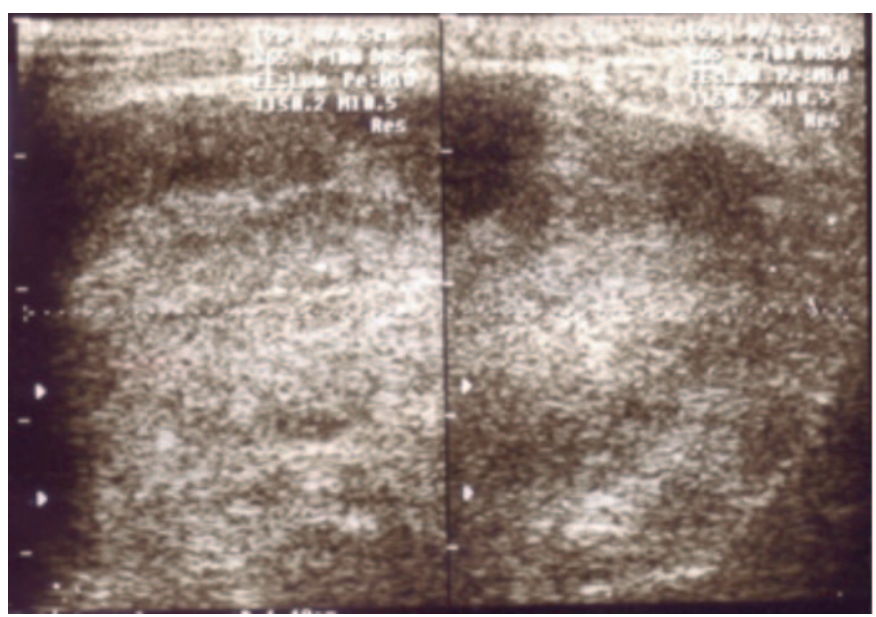

Fig. 1. Ultrasonographic B-mode image shows a large, well marginated, hypoechoic, solid mass.

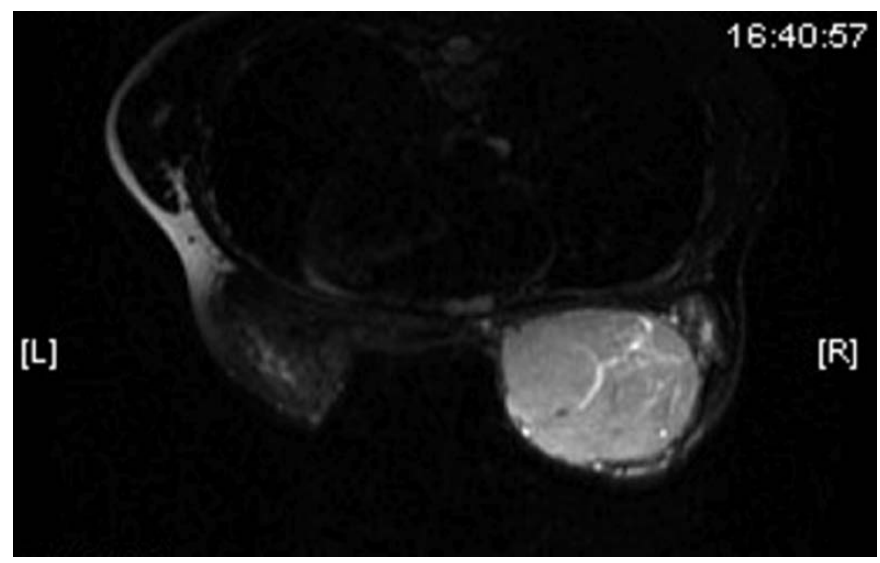

Fig. 2. Axial T2-weighted image shows a large, hyperintense, well marginated mass.

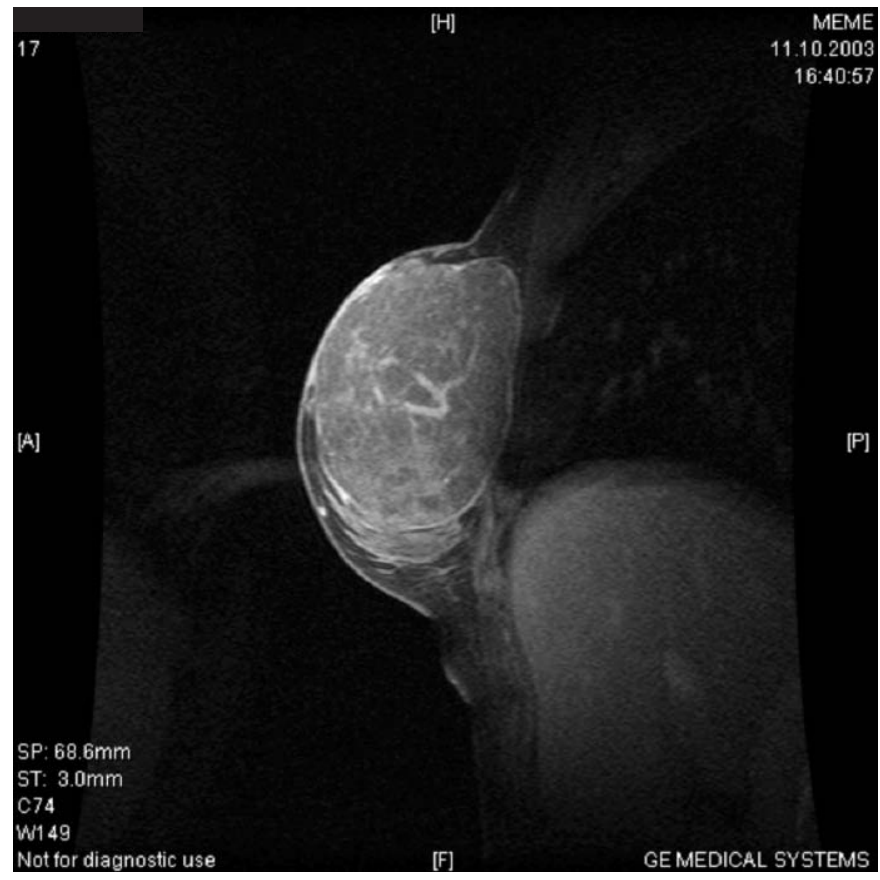

Fig. 3. Sagittal T2-weighted image shows a large, hyperintense, well marginated mass covering the pectoral muscle. 


\section{Discussion}

Breast sarcoma is a rare type of breast cancer arising from the mesenchymal tissue of the breast. It represents $1 \%$ of all primary breast malignancies and $5 \%$ of all sarcomas, with an approximate incidence of 17 new cases per 1 million women [4]. Breast sarcoma is mostly diagnosed in patients who are in their 5 th or 6 th decade of life $[3,5]$. However, the patient in our case was only 14 years old. There is a small number of breast sarcoma in children and adolescents reported in the literature [4]. The risks for developing breast sarcoma are largely unknown. Some authors showed a significant correlation between external beam radiation of the breast or chest wall and sarcoma [6]. Despite the low incidence of malignant mesenchymal sarcoma of the breast, the disease may show an aggressive course leading to mortality as in our case.

Mammography is non-specific in the case of breast sarcoma, and usually demonstrates a non-spiculated dense mass, in most cases without microcalcifications. Therefore, the advantage of mammography in demonstrating microcalcifications is often not available in these cases. In our case, we did not use mammography because of the patient's age. In this young age, the primary radiological imaging method is ultrasonography which also has been suggested to be more successful than mammography in diagnosing breast sarcoma. On sonography, the majority of breast sarcomas appear hyperechoic with no shadowing. However, in our case, the mass had hypo-/hyperechoic areas. Furthermore, MRI may be helpful in the diagnosis of breast malignancy including sarcoma, as malignant tumors display rapid enhancement with 'washout' characteristics and lobules [6].

The treatment of choice with breast sarcoma is surgical resection. The most important factors affecting local control and survival rates are the achievement of a complete microscopic resection of the tumor, and the mass size being greater than $5 \mathrm{~cm}[4,5]$. The integration of axillary dissection into the surgical procedure depends on the presence of palpable axillary lymph nodes. Because these tumors usually spread via the blood, however, lymphatic spread is rarely seen [3, 5]. No positive axillary lymph nodes were found in our case. However, the diameter of the mass was more than $5 \mathrm{~cm}$, and this was a poor prognostic factor for our patient. The role of chemotherapy and radiotherapy in the treatment of breast sarcoma has not yet been defined, but some authors suggest using them for local and systemic control. There is no consensus on the optimal chemotherapy protocol, but most chemotherapy reportedly used in patients with breast sarcoma consisted of doxorubicin-based regimens [7]. In our patient, we performed a mastectomy with axillary lymph node sampling to provide local control. Also, radiotherapy and chemotherapy were performed for locoregional and systemic control.

In conclusion, well marginated masses are generally interpreted as benign, especially in young females. Due to the rarity of breast sarcoma and inadequate imaging methods to establish an exact diagnosis, radiologists and clinicians may misdiagnose and merely follow these tumors. The histology of the patient may be the leading factor for the management of these tumors as was the case in our patient. Even in very young patients, a progressively growing breast mass should alert the clinician to investigate for malignancy and verify the results by biopsy.

\section{Disclosure Statement}

The authors declare that they have no conflict interests.

\section{References}

1 Chung EM, Cube R, Hall GJ, González C, Stocker JT, Glassman LM: From the archives of the AFIP: breast masses in children and adolescents: radiologic-pathologic correlation. Radiographics 2009;29:907-931.

2 Jayasinghe Y, Simmons PS: Fibroadenomas in adolescence. Curr Opin Obstet Gynecol 2009; 21:402-406.
3 Teo T, Wee SB: Clinically 'benign' breast lumps: sarcoma in hiding? - Case reports and literature review. Ann Acad Med Singapore 2004;33:270-274.

4 Adem C, Reynolds C, Ingle JN, Nascimento AG: Primary breast sarcoma: clinicopathologic series from the Mayo Clinic and review of the literature. Br J Cancer 2004;91:237-241.

5 Altıntoprak F, Serin K, Ozcinar B, Eren T, Yavuz E, Ozmen V: Undifferentiated sarcoma of the breast. J Breast Health 2007;3:169-172.
6 Al-Benna S, Poggemann K, Steinau HU, Steinstraesser L: Diagnosis and management of primary breast sarcoma. Breast Cancer Res Treat 2010;122:619-626.

7 Sueta A, Yamamoto Y, Inoue K, Kuriwaki K, Iwase H: Stromal sarcoma of the breast with lung metastases showing a clinical complete response to doxorubicin plus ifosfamide treatment: report of a case. Surg Today 2011;41:1145-1149 